\title{
NUMBER CONCEPT GAMES ON TABLET COMPUTERS: INTERACTIVE AND ATTRACTING THE INTEREST OF PRE-SCHOOLERS STUDENTS
}

\author{
Abdul Halim Masnan and Maizatul Akhma Sa'at \\ Department of Early Childhood Education, \\ Faculty of Education and Human Development, \\ Universiti Pendidikan Sultan Idris, 35900 Tanjong Malim, Perak, Malaysia \\ *Corresponding author: abdul.halim@fppm.upsi.edu.my, \\ maizatulakhma@fppm.upsi.edu.my
}

Published date: 20 January 2017

To cite this article: Abdul Halim Masnan \& Maizatul Akhma Sa'at. (2016). Number concept games on tablet computers: Interactive and attracting the interest of pre-schoolers students. Asia Pacific Journal of Educators and Education, 31, 1-13. http://dx.doi.org/10.21315/apjee2016.31.1

To link to this article: http://dx.doi.org/10.21315/apjee2016.31.1

\begin{abstract}
Learning aided by tablet computers is one of the methods in acquiring knowledge interactively that involves animations and games that are useful to children. Games based on the concept of mathematics (numbers 1-5) were implemented regarding the suitability of the activity for pre-schoolers learning. This study attempted to identify the effects of using tablet computers towards the understanding of early mathematical concepts for pre-schoolers. Two research questions were identified, which involved a teacher and 10 four years old students in the National Child Development Research Centre (CDRC) in Universiti Pendidikan Sultan Idris (UPSI). The first research question involved the appropriateness of the game software concept using tablet computers. Meanwhile, the second research question involved the level of understanding of the numbers concept of pre-school children using tablet computers. This study involved a qualitative approach through interviews of classroom teachers, student's observations using tablet computers and test for pre-schoolers on number concepts. This study found that it was easy for classroom teachers to teach the game software of number concept using tablet computer. Classroom teachers also expressed their satisfaction towards using the game software of number concept that was more child-friendly. Moreover, children were also found it easy to use tablet computers in carrying number concept activities. The test of understanding the number concept showed that most children were able to determine the form, count, pronounce, and write the numbers of 1-5 well. As a conclusion, this study can help pre-school teachers in using tablet computers and suitable games of number concept for teaching and learning of four years old students.
\end{abstract}

Keywords: tablet computer, the numbers concept, pre-schoolers

(C) Penerbit Universiti Sains Malaysia, 2016 


\section{INTRODUCTION}

Teacher education bodies, researchers and educators in the field of student's early education (International Society for Technology in Education [ISTE], 2007; National Association for Education of Young Children [NAEYC], 1996) stated that the use of tablet computers through technology resources, through contact and game programme are able to solve the problems in a teaching component. The use of tablet computers in classroom is meaningful through children's understanding of the software used. According to Swaminathan and Wright (2003), the importance of using technology encourages children's thinking to solve problems, especially those involving the number concept.

Parker (2008) in his study has found that lessons using computers increases the interest and attention of students, encourages feedbacks, offers intellectual learning experience, as well as helps in fostering literacy and high level thinking skills among students. Therefore, teaching that integrates the use of tablet computers is necessary in order to produce more interesting and effective implementation (Course \& Chen, 2010).

\section{PROBLEM STATEMENT}

One of the challenges in the education system in Malaysia is to shift the paradigm of the teachers towards the latest changes in teaching and learning method that use computers and ICT (Information and Communication Technology) facilities as an alternative approach. Teachers need to find the idea of learning and teaching aids that are interesting to motivate interest and create attractiveness in the educational curriculum learning process (Liew, 2007).

Introduction to numbers plays an important role in students' learning of mathematics. Number concept describes the quantity or amount of objects for a group, which is the quantity characteristics of the object, whereas figure is a symbol or sign that represents and reflects the concept of numbers. The interest in the number concept has been expressed in the guidelines of the National Standard of Pre-school Curriculum (Ministry of Education, Malaysia, 2009). Children aged four to six years old should be exposed to the number concept since childhood. However, they only memorise without understanding the meaning of each particular number. The approach through multimedia activities is rarely used by teachers in pre-school due to the lack of materials and software that are appropriate and interesting to students. 
Playing activity is fundamental in the learning process for students. Games that use tablet computer is one of the interactive ways for this activity, which involves animation and the games that are useful to students. However, there are problems as students are less focused on the instruction and explanation by the teachers when tablet computers are used in the learning session. This is because students are busy playing with the tablet computer regardless of the explanation by the teacher. Therefore, the use of tablet computers is strongly encouraged, but monitoring is necessary for teachers to plan good and efficient students' learning activities.

\section{PREVIOUS LITERATURE REVIEW}

Abdul Halim (2008) stated that various software can be used to influence students' knowledge by providing a meaningful experience and enhance students' skills in Mathematics and Science. Therefore, teachers need to be exposed to various methods of how ICT is used as a medium to access information from the Internet, studying phenomena using simulations or observing demonstration of a scene, helping students to perform their tasks such as writing essays, drawing pictures and others (Maier \& Warren, 2002; Jonassen, 2003).

Based on previous studies, the use of ICT in the students' early stages shows that the exposure to multimedia computers can stimulate and motivate students to learn better, faster and more efficient. In addition, early exposure to ICT is able to help students in developing critical thinking, improve creativity, exploring various areas, applying knowledge and skills in a situation, as well as increasing students' attention and interest. According to Alessi and Trollip (2001), there are several advantages for students for learning through ICT, such as students can access learning materials anytime and anywhere, can be networked from additional resources available across the world, various forms of communication channels are available to be used by students and teachers, as well as managing and updating materials have become easier and faster.

Various new methods have been proposed to integrate technology into curriculums in promoting students' active involvement. Among them are active learning in pre-school, technology and students' drawing, the development of technology in classrooms, the potential of using tablet computers in classrooms and also setting technology standards and the use of tablet computers for students.

According to Barton and Collura (2003), students have many advantages in improving high writing and organisational skills with the use of tablet computers. 
Based on the studies performed, we can see that the students are very excited when their teachers give them the opportunity to use tablet computers in learning sessions.

Learning how to use tablet computers can be associated with the approach of learning through play. Students at this age are very keen to learn while playing. They should not focus on the study immediately without any of the activities provided by the teacher. For example, the use of tablet computers is able to attract students' interest to learn. They will feel more confident to learn and not get bored with the lesson while playing. Playing activities are essential for the development of students in various ways. Students learn skills about the world around them effectively through play. Once they understand new concepts and repeat it again during the game, they master the concept for the next level.

Various software that are able to stimulate students' development are also given to pre-school classes. Pre-schoolers are given the freedom to choose their own software according to their ability, age and interest. Therefore, this software material is expected to meet the educational requirement that contains the element of knowledge and tutorial characteristics (Rohani, Nani, \& Mohd Sharani, 2003). Therefore, this study aims to identify the effectiveness of multimedia software using tablet computers towards the understanding of the number concept for pre-schoolers.

\section{OBJECTIVE OF THE STUDY}

This study aims to identify the teaching of multimedia software using tablet computers towards the understanding of number concept for pre-schoolers.

\section{RESEARCH QUESTIONS}

1. How compatible is the number concept software using tablet computers by pre-school teachers?

2. Sample and location of the study: The study involved a class in the National Child Development Research Centre (NCDRC). A pre-school teacher and 10 four years old students were involved in this study. 


\section{RESEARCH DESIGN}

The study was performed with the involvement of a qualitative approach. Qualitative research was used to identify the suitability of the multimedia software assisted by tablet computers that are used by pre-school teachers in the teaching number concepts (Bogdan \& Biklen, 2007). The study involved the observation of students' teaching and learning process in a classroom.

The study also examined the changes in the students' understanding on the number concept before and after using tablet computers. A set of questions regarding the number concept was used to compare the achievement of selected students.

\section{SAMPLE AND LOCATION OF THE STUDY}

The study involved a class in the National Child Development Research Centre (NCDRC). A pre-school teacher and 10 four years old students were involved in this study.

\section{IMPLEMENTATION OF THE STUDY}

There are three levels of the study:

1. Students learnt the number concept assisted by tablet computers.

2. In-depth interviews were conducted for the classroom teacher after the implementation of teaching process.

3. The students' comprehension test of the number concept was tested once again. 
The following Figure 1 shows an example of the research flow:

Observation

Corview

Comprehension Test
Reviewing students' learning activities using tablet computers

Feedback from teachers

The feedback of students' understanding on the number concept

Figure 1. The implementation of the study involving qualitative approach

\section{TECHNIQUES FOR COLLECTING OBSERVATION DATA}

Observations were performed towards the behaviour of 10 pre-school students during the class. The study involved five girls and five boys. This observation was made in its entirety and in accordance with the observations reported in the form of certain aspects such as:

1. Observing students' habit before the classroom teacher started teaching.

2. Watching students' reaction when tablet computers were given to them

3. Observing students' behaviour in learning activities using tablet computers

4. Watching students' reaction when worksheets were given to them

\section{DOCUMENTS ANALYSIS}

Based on the planning of action-implementation, the researcher had given the worksheets to pre-schoolers. The researcher had then analysed the worksheets of pre-school students. The data is based on the findings of the worksheets, which are the number of questions that are answered correctly and incorrectly. After the action, they have mastered the concept and answered the questions correctly and accurately. 


\section{FINDINGS}

\section{Research Question 1}

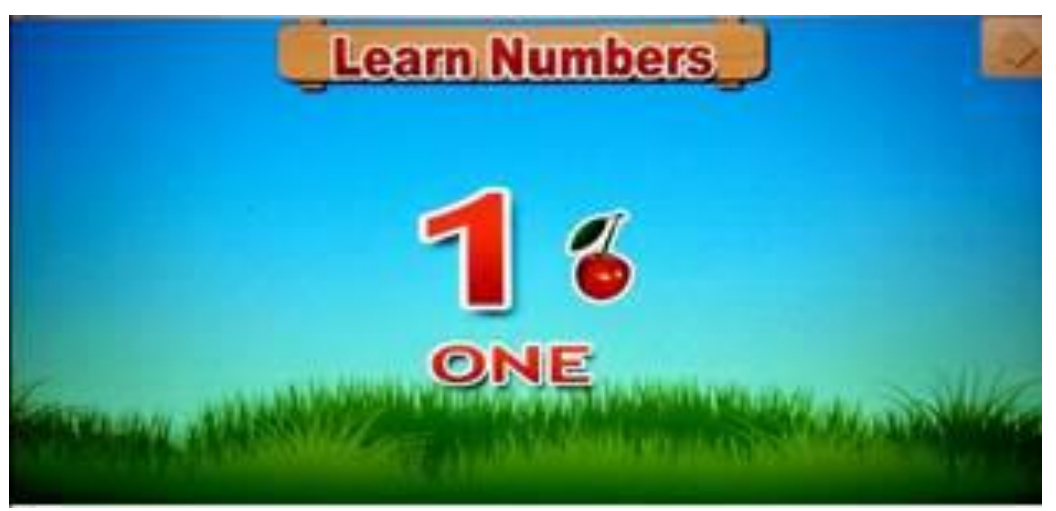

The suitability of two types of number concept games in the Play Store programme using tablet computers. The games are The Kids Learning Numbers and The Numbers. The finding is based on students' observations and strengthening exercise.

\section{Game: The Numbers}

Activity 1

Knowing number $1-5$

Based on the observations, all of the students found it easy to conduct the activity by identifying number $1-5$ and touching the numbers and quantity of the numbers repeatedly.

\section{Activity 2}

Sounding number $1-5$

Based on the observations, all of the students were able to touch and sound the number based on the picture displayed and sound the number assigned in the game repeatedly. They always pressed the numbers and pronounced each number in English correctly.

\section{Activity 3}

Recognising number $1-5$

Based on the observations, 7 out of 10 students could identify the numbers that were shown during the activity. The boys were less familiar with the pronunciation and identification of the assigned numbers due to lack of clear audio compared to girls. 


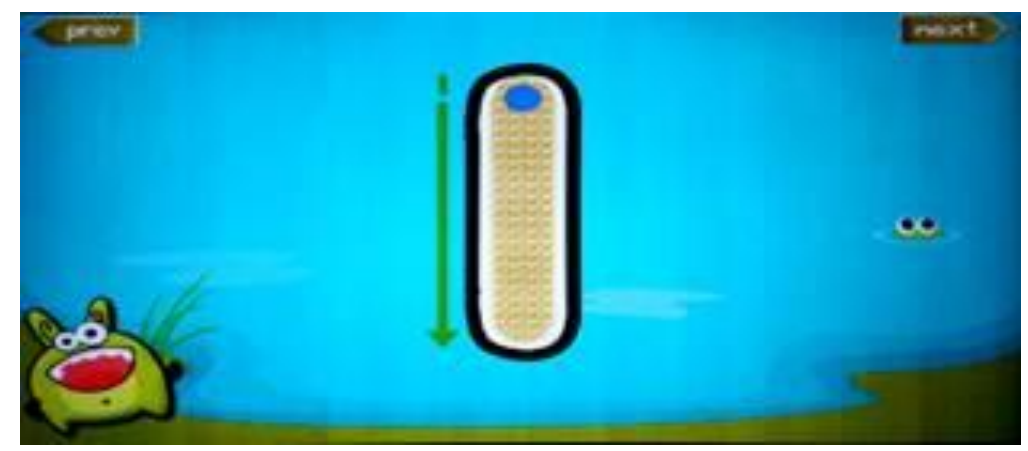

Game: Kids Learning Numbers

Activity 4

Writing number $1-5$

Based on the observations, all of the children were able to follow the instructions and wrote the numbers with the steps given correctly. They tried to write each assigned number until completion.

\section{Summary of the findings}

In overall, the activities involving 'The Numbers' game could be used properly by the children. They easily accepted the display of each prepared activity either in the form of graphics and colorful cartoons, the sound for each instruction and number pronunciation, and the use of hands to remove and press some of the display of available activities.

\section{Research Question 2}

The effect of tablet computers towards the understanding of the number concept for pre-schoolers through classroom teacher's interviews and students' observation.

\section{Interview with classroom teacher}

According to the teacher, the method of using tablet computers in introducing the basic concept of number $1-5$ for 4 years old children is very suitable and attractive. The following are several things that involve the effect of using tablet computers towards understanding the number concept among pre-schoolers.

\section{The skills using tablet computers}

According to the classroom teacher, most children know how to use tablet computers using their fingers. They are exposed to the touch screen practices 
involving several gadgets such as tablet computers (Samsung and iPad) and smartphones. Children were found to easily use the provided tablet computers in a good manner. This facilitates the classroom teacher to conduct activities smoothly.

The interest towards the number concept

According to the classroom teacher, this activity can help to attract students' interest in early learning of mathematics easier and quicker. Students were found preferred to carry out the activities more diligently and fun. The teacher also added that the display of interesting graphics and audio encouraged children to engage with the learning activities in a relatively long period. They also tried until they succeeded in an activity, and this indirectly increased their willingness to do it correctly.

\section{The understanding of the number concept}

The classroom teacher explained that a suitable game is able to help students to understand the number concept faster. The teacher added that students are easier to understand number $1-5$ based on the number, value, pronunciation and writing through improved activities provided to them. Clear instructions and interesting activities are able to facilitate students' understanding more quickly and effectively.

\section{Observations of Students' Learning Activities}

The findings involved five boys and five girls without basic knowledge of number $1-5$.

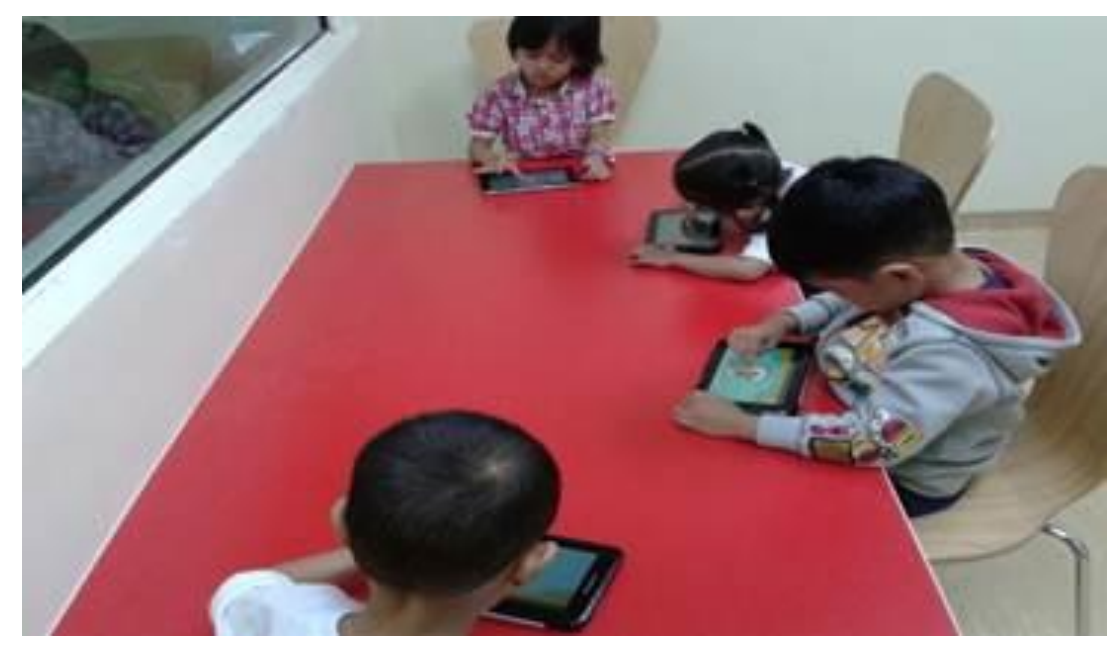


From four activities involving two types of games, the students were found to be doing well. Each student was able to perform the assigned activity until completion.

The data collected during this investigation are presented in Table 1.

Table 1. Findings based on the observation of children's activities

\begin{tabular}{clcccc}
\hline \multirow{2}{*}{ Type of Activity } & \multirow{2}{*}{ Title of Activity } & \multicolumn{3}{c}{ Passing Percentage (\%) } \\
\cline { 3 - 6 } & & \multicolumn{2}{c}{ Pass } & \multicolumn{2}{c}{ Fail } \\
\cline { 3 - 6 } & Knowing number 1-5 & 5 & 5 & 0 & 0 \\
\hline 1 & Sounding number 1-5 & 4 & 5 & 1 & 0 \\
2 & Recognising number 1-5 & 3 & 4 & 2 & 1 \\
3 & Writing number 1-5 & 5 & 5 & 0 & 0 \\
\hline
\end{tabular}

Overall, nearly $80 \%$ of male students mastered the basic number of 1-5. Meanwhile, $90 \%$ of female students mastered the basic number of 1-5.

\section{DISCUSSION OF THE STUDY}

\section{Compatibility of Tablet Computer Games}

Selection of suitable games can facilitate classroom teachers to plan activities involving the number concept for students. Teachers are able to identify certain gaming activities that are effective and can be carried out well for all students in class.

Compatibility features of games involving attractive graphics, clear sound, and the course of activities organised in accordance with students' developmental stage are able to provide a positive impact towards their understanding of the number concept. The selection of suitable and particular learning games can become a guide for other pre-school teachers to use these activities to ensure a smooth and faster process of students' understanding towards the number concept. 


\section{The Effect of Using Tablet Computers towards the Understanding of the Number Concept for Pre-Schoolers}

The number concept games help and motivate students to perform better in activities. In addition, the gaming method that uses tablet computers is also able to enhance students' memory in the process of learning and understanding the concept of numbers. With that, students are no longer confused and are directly able to practice writing and counting the basic numbers (1-5).

This activity attracts pre-schoolers' interest to learn mathematics. These tablet computer game activities are fun and comfortable teaching and learning process for pre-schoolers.

The use of tablet computers is also able to accelerate the learning process of basic numbers (1-5). Students learn various basic knowledge of number 1-5, identifying the numbers, and learning the pronunciation of particular numbers. Students will also be exposed to the aspect of writing number 1-5 correctly. This can help students in the aspect of higher knowledge and skills involving writing, counting and reasoning (Malaysian Ministry of Education, 2010).

\section{IMPLICATIONS AND RECOMMENDATIONS OF THE STUDY}

The implications of this study towards the national education are based on the importance of the ICT used within the National Standard of Pre-school Curriculum (Ministry of Education, Malaysia, 2009) that needs to be strengthened in ensuring the balance of using ICT at each pre-school. In addition, pre-school teachers should be given more exposure towards the use of computers especially in using tablet computers to meet children's needs more quickly and effectively.

The implications of this research towards children's needs are to increase the use of tablet computers at an early age in order to improve their intellectuality, creativity, literacy and numeracy development. In addition, the use of suitable games corresponding to the number concept for children can be enhanced through problem-solving activities and able to attract their interest in any learning cores. Children are also able to memorise longer and quickly understand what they have learnt.

The researcher recommends for further studies involving pre-schoolers in other districts. This is to ensure that the findings obtained can be generalised and provide a more accurate idea. This study only focuses on the use of tablet 
computers and the effect towards mastering early mathematics of pre-schoolers. Therefore, the researcher suggests more extensive further research by studying the effect in using tablet computers through other cores that are available in the National Standard of Pre-school Curriculum guide.

\section{CONCLUSION}

Previous studies have reported the importance of using information technology that involves tablet computers towards students and teachers. This study is expected to help pre-school teachers in providing interactive multimedia software that is suitable and interesting for the needs and development of students. In addition, this study also identifies suitable methods of teaching mathematics with the use of tablet computers, which involves the concept of early mathematics number among pre-schoolers.

\section{REFERENCES}

Abdul Halim Masnan. (2008). Hubung kait kemahiran penggunaan komputer perisian ke atas pencapaian matematik kanak-kanak prasekolah. Proceedings of International Conference on the Education of Diverse Learners (ICELD 2008), Universiti Kebangsaan Malaysia, Bangi.

Alessi, S. M., \& Trolip, S. R. (2001). Multimedia for learning (3rd ed.). USA: Pearson Education.

Barton, C., \& Collura, K. (2003). Catalyst for change. T.H.E. Journal, 31(4), 39-42.

Bogdan, R. C., \& Biklen, S. K. (2007). Qualitative research for education: An introduction to theory and methods (5th ed.). Boston, MA: Pearson.

Course, L. J., \& Chen, D. W. (2010). A tablet for young children? Exploring its vialibility for early childhood education. Journal of Research on Technology in Education, 43(1), 75-98. http://dx.doi.org/10.1080/15391523.2010.10782562

International Society for Technology in Education (ISTE). (2007). National educational technology standards for students. The next generation. Retrieved 9 October 2013 from http://www.iste.org/inhouse/nets/cnets/students/pdf/NETS_for_ Students_2007.pdf

Jonassen, D. H. (2003). Using cognitive tools to represent problems. Journal of Research in Technology Education, 35(3), 365-381. http://dx.doi.org/10.1080/15391523. 2003.10782391

Liew, K. (2007). ICT in education: An action learning approach using soft system methodology. Jurnal Penyelidikan Pendidikan Guru, 3, 17-38.

Ministry of Education, Malaysia. (2009). National standard of pre-school curriculum. Kuala Lumpur: Malaysian Ministry of Education.

Maier, P., \& Warren, A. (2002). Literacy technology in learning and teaching. London: Kogan Page. 
National Association for Education of Young Children (NAEYC). (1996). Technology and young children ages 3 through 8. Position statement of the National Association for the Education of Young Children. Retrieved 10 August 2013 from http://naeyc.org/about/positions/pdf/PSTECH98.PDF

Parker, L. L. (2008). Technology-mediated learning environments for young English language learners: connections in and out of schools. New York: Lawrence Erlbaum Associates.

Rohani Abdullah, Nani Menon, \& Mohd Sharani Ahmad. (2003) Panduan kurikulum prasekolah. Pahang: PTS Publications \& Distributors Sdn. Bhd.

Swaminathan, S., \& Wright, J. L. (2003). Education technology in the early and primary years. In J. P. Isenberg, \& M. R. Jalongo (Eds.), Major trends and issues in early childhood education: Challenges, controversies, and insights (2nd ed., pp. 136-149). New York: Teachers College Press. 